Contents List available at VOLKSON PRESS
Multidisciplinary Inclusive Education, Management
and Legal Services (MIEMLS)
Journal Homepage: https://topicsonsocialdevelop.com
DOI: $10.26480 /$ ismiemls. 01.2018 .27 .28

\title{
ON THE RIGHT OF REVOCATION IN THE GIFT CONTRACT
}

\author{
Ma Hui, Fu Yun \\ College of Arts and Law of Wuhan University of Technology, Wuhan Hubei,430070, China \\ *Corresponding Author E-mail: fuyunkuaile@qq.com
}

This is an open access article distributed under the Creative Commons Attribution License, which permits unrestricted use, distribution, and reproduction in any medium, provided the original work is properly cited.

\section{ARTICLE DETAILS}

\section{Article History:}

Received 26 June 2018

Accepted 2 July 2018

Available online 1 August 2018

\section{ABSTRACT}

Gift contract is a kind of unilateral, free of charge, integrity of the contract, because it has such features, so the law endows the donative person any gift contract cancellation right to protect their rights, but the exercise is to have a limit of the right, or it will lead to the abuse of rights, violates the principle of good faith and fairness.

\section{KEYWORDS}

Gift contract, Arbitrarily revocation right.

\section{THE CONCEPT OF THE RIGHT TO RESCIND THE GIFT CONTRACT ARBITRARILY}

The right of revocation of gift contract is a kind of powerful forming right, which can unilaterally and compulsively restore the contract to the state before the conclusion without the consent of the other party [1]. Any cancellation right of the donor is donative person a kind of special rights granted lawmakers, before of the gift property rights transfer, the donor can not add any restrictions to the exercise of the rights, but also do not need to pass the consent of the contract to the other party can make the contract to reply to the state before the donative contract is signed. General donative contract signed based on certain moral or emotional considerations, if forced donative person take effect once the contract is formed, it must be performed, is to affect the enthusiasm of the parties, also not conducive to the spread of social equity and justice [2]. However, if this right is not restricted, it will also damage the trust interests of the recipient, violate the provisions of the principle of good faith in the civil law, and have a bad impact on fairness and justice. China's contract law also has strict provisions on the restriction of this right.

As for article 186 of The Contract Law of China, the donor may revoke the gift before the transfer of the gift property rights; The provisions of the preceding paragraph shall not apply to a gift contract of the nature of a public welfare or moral obligation, such as disaster relief or poverty alleviation, or a gift contract notarized [3]." According to the provisions of this law, there are the following restrictions on the right to revoke the gift contract arbitrarily:

(1) The exercise of the right to rescind a gift contract is limited to a contract concluded either orally or in writing. The donor may not cancel the gift contract after it has been notarized. Gift contract after notarized at the notary office has fully illustrates the donative contract both sides for the gift of careful consideration, donative contract at this time have considerable legal aspects of recognition, so can not be any revocation of the contract.

(2) The donor shall not revoke the property and other rights and interests that have been transferred. If the transfer of property rights and so on has delivered the gift of, based on debt elimination, donative contract has been completed, and the end of the rights and obligations of the contract, if cancellation is allowed at this time is to fulfill the contract, is obviously unfair.

(3) It is not allowed to revoke the donation of social welfare and moral obligation. Because this gift has social influence and moral factors, the donor can not exercise the right of revocation without restriction.

Some scholars think freely dispose of according to the civil rights and protected by law principle, the gift is the essence of which is the donor can be dealt with according to law for their own property rights of a legal way, the donor can exercise of the rights of freedom, as to whether a gift or a gift who, after the gift of repentance, shall be determined by their own donor, the law and shall not interfere with others [4]. The author thinks that this idea is clearly in the legislative spirit and the rules for civil rights in our civil law although they are broad, and gives the citizens greater autonomy, but the exercise can't abuse of the right, otherwise the fair principle and other basic principle, at the same time, according to the provisions of the The Contract Law of China article 52 of the contract is invalid as you can see lawmakers also the abuse of it is strictly prohibited. Gift contract is a legal act of both sides, one side said donative, one party accepted, so the author thinks that for any cancellation right shall be limited in a certain range, to protect the interests of the done trust.

\section{PROBLEMS EXISTING IN CHINA'S LEGISLATION}

For the right of arbitrary revocation, the legislator does not have too many restrictions on the donor to exercise the right. Thus, any gift contract cancellation right only focus on the maintenance of the rights of the donor, ignoring the donate based on the trust of the donor's trust to pay interest, this conflicts with "contract law" legislation intention. During any gift contract cancellation right is not scheduled rules, it is unfavorable to the death of debt and keep the contract, easy to cause social disputes, but also to the court and other departments deal with disputes, the decision to increase the difficulty [5]. And for any cancellation right, because there is no specific judicial interpretation in the judicial practice in China and the relevant cases instruction, for in the trial of complex problems that cannot be good grasp, brought great difficulty to the judicial personnel, due to the large any cancellation right is right, the judiciary generally can only according to the provisions of the law support the donor appeal, but little in the case of entity to the protection of the done, caused some adverse effects, as well as bad with fairness and justice. 


\section{IMPROVEMENT OF THE SYSTEM OF ARBITRARY REVOCATION RIGHT}

\subsection{Define the corresponding period of exclusion}

If the donor during the exercise of any cancellation right not sure, this will make the contract the other party's interests in an unstable state, but also destroyed the trusty interest of the other party of the contract, is not conducive to the spread of social equity and justice, as well as the trial institutions brought trouble when dealing with the kinds of case [6]. Therefore, legislation should be made to stipulate the corresponding period of exclusion, so as to balance the rights and obligations of both parties in the contract and better protect the rights and interests of the donor and the recipient.

\subsection{Stipulate the revocation right of the donee}

In legislation, the right to revoke the donor is stipulated, but the idea of whether the recipient is willing to accept the gift is ignored. It is suggested to adopt the provisions of Japanese civil law to grant the recipient the corresponding right to revoke the gift. Gift contract although is donative person assumes the obligations of the contract unilaterally, however, we still want to consider the idea of the donee, if the recipient is not willing to accept the gift, so the law can not only protect the rights of the donor and ignore the rights of the donee, so the legislation also endows the donee shall cancellation right, the right to donative contract both sides can get a good maintenance.

\section{CONCLUSION}

As the saying goes, "if the people are well off, they need not go back to the past."The law that works is not engraved on marble or bronze, but on the hearts of citizens. The people's faith in the rule of law will not come out of thin air. Gift contract has the vital significance in reality, adjust the interpersonal relationship, make the relationship more harmonious between person and person, even to a certain extent, balance of social wealth, rich the kinds of contract, also can promote the economic development and social stability. As the scholars of civil law in Taiwan have said, gift contracts are not only for the recipient to receive property, but also for the donor to receive spiritual satisfaction. The author hopes that this article can play the effect of throwing bricks and introducing jade, so that the gift contract system can be more perfect and reasonable.

\section{ACKNOWLEDGMENTS}

First, I would like to thank my thesis advisor, Ma Hui teacher of the Wuhan University of Technology. Ma Hui teacher for my thesis research direction to make the guiding opinions and recommendations, in a timely manner in the process of thesis writing difficulty and confusion to give good advice to me, put forward a lot of beneficial to improve sex, invested a lot of effort and energy. Teacher Ma Hui sincerely thank you help! At the same time, I would also like to thank the teachers and all the students of Wuhan University of Technology for their teaching. Thank you!

\section{REFERENCE}

[1] Ziheng, S. 2016. Questioning the right to revoke the gift arbitrarily. Journal of Henan university, 1.

[2] Wenjun, W. 2010. On the arbitrary cancellation of gift contract. Law BBS, 6.

[3] Hong, Y. 1999. Contract law of the People's Republic of China and comparison at home and abroad, law press.

[4] Xijinping's second volume on governance, Beijing foreign language press, 2018.

[5] Weizao, C. 2015. German civil code, legal press.

[6] Yashin, K. 2017. Amendments to the Japanese civil code, translated by Zhu ye and Zhang ting, Peking University press.

\section{ABOUT THE AUTHORS}

Fu Yun,Master degree, College of Arts and Law of Wuhan University of Technology,Wuhan Hubei,430070, China

Ma Hui, Doctor's degree,College of Arts and Law of Wuhan University of Technology,Wuhan Hubei,430070, China 